\title{
USE OF GEOTECHNOLOGIES IN INTEGRATED ASSESSMENT OF URBAN DRAINAGE, WATER RESOURCES AND URBANIZATION
}

\author{
E. PACHECO \& A. FINOTTI \\ Department of Sanitary and Environmental Engineering, Federal University of Santa Catarina, Brazil.
}

\begin{abstract}
Water resources historically are impacted by urbanization. Urban drainage, which is an inherent consequence of urbanization, is one of the major elements of impact on water resources in the city. However, urban drainage is almost always treated as a sanitation task, and its intrinsic relation to water resources is often not taken into consideration. As a result, drainage management is performed separately and disconnectedly from urban development management and water resources management. By means of a study on the Campeche aquifer in Florianópolis, we have shown that the disconnected management of these three elements creates serious urban and environmental problems. With an integrative method, we have sought to bring previous studies together, by means of geotechnologies such as GIS, to highlight the key elements for the integration of the sectors responsible for management. The present study suggests the creation of a unified database for the drainage network, hydrography and urban infrastructure, as well as the standardization of projects by means of sanitation, water resources and stormwater management plans. We have also shown how the use of these tools can be extended to other locations, thus proving a very promising integrative methodology.

Keywords: GIS, integrated management, urban drainage systems, urbanization, water resources.
\end{abstract}

\section{INTRODUCTION}

Water resource management involves the interfaces of surface water, stormwater and groundwater within the hydrologic cycle and the sustainable use of these by urban infrastructure. The relations established between environmental sanitation services, urbanization and the water cycle can be summarized in three key points, according to Vargas [1]. The first point refers to the urbanization that has largely relied on remedial actions that include both supplying the cities with essential resources and excluding adverse elements to health, safety or comfort of urban populations. The second point includes the direct negative impacts of urbanization on the hydrological cycle, which culminate in the loss of potential water use. Finally, there is the issue of instruments and actions taken by the government to control the problems related to interactions between urbanization, sanitation and the water cycle.

In the late 1990s, Brazil developed different tools aimed at integrated water resource management in an attempt to reduce the problems related to urbanization, sanitation and the water cycle. The Law of Water Resources [2] was a milestone in the transition from the traditional political-administrative division to land management based on watersheds as a planning unit; the Law of Basic Sanitation [3] has defined the integration of different sets of services, infrastructure and operating facilities on the processes of: drinking water supply; sewage; solid waste management, drainage and urban stormwater management.

Aiming to diagnose and predict future negative impacts of urbanization on the hydrological cycle, various tools have evolved in recent years, including simulations and mathematical/computational models that, combined with GIS technologies, have allowed the production of thematic maps by using satellite images, fieldwork and georeferenced database. These new tools are extremely important not only for diagnosis but also for management and planning of urban waters with a systemic 
and integrated vision of urban infrastructure for water resources (surface water, stormwater and groundwater).

In the specific case of urban drainage, the issue of the planning unit proves decisive; the downstream impacts of stormwater drainage systems go far beyond political-administrative territorial units, as they comprise the watershed as a whole [4,5]. Actions upstream the watershed impact all water resources and transfer environmental problems to different municipalities downstream. The planning and management of urban drainage based only on the road system is a misconception already widely documented [6,7] but still performed in many cities of the world, thus causing further flooding problems.

In this article, a methodology is presented for integrated analysis of urban water resources and environmental sanitation by using remote-sensing techniques. The main objective is the integration of different information plans, all already available, to bring out details not obtained with the isolated analysis of information. The methodology was applied to an urban aquifer that is connected to two watersheds in the city of Florianópolis, Santa Catarina, Brazil.

The watersheds selected for the case study were chosen because they have surface and underground water bodies impacted by accelerated urbanization. This region lacks effective water resource management practices, as well as integration of these practices with sanitation facilities; there is also the lack of cohesion of these ones with other organizational systems of the urban environment. According to the Basic Integrated Municipal Sanitation Plan (PMISB - Plano Municipal Integrado de Saneamento Básico) [8] conducted by the city of Florianópolis, sanitation services are deficient mainly in terms of served water collection and treatment and urban drainage. Uncontrolled urbanization ultimately leads to urban situations similar to those found at the study site. Thus, this methodology is expected to be able to help identify impacts and point to alternative water management practices at these locations.

\section{MATERIALS AND METHODS}

The study was conducted in four phases: a collection of technical data on the area of study, preparation of base maps with information plans, integration of base maps in a GIS environment, assessment of drainage and water resource management practices and, ultimately, the application of geotechnologies for visual identification of historical changes in water resources and drainage network. Most impacted regions of the aquifer were selected for detailed study.

The first phase, technical data collection, was done along 2013 in all municipalities departments that have any link with water management, sanitation and urbanization. Some key documents had to be updated and others needed completely reconstitution. In this phase, we collected a number of works and information on water resources and sanitation that overestimate our initial expectative. But we also detected a complete disconnection between municipality departments and also in the way the information was used by them. The information we need to our work was available in studies of good quality. The main defeat to us was in the integration of the information. Unfortunately some maps or figures were previously generated in platforms that did not allow a substantial change in their graphical quality level, what do not interfere in the essential information they bring out to our study.

In the second phase, the hydrographic map was reconstituted from an available map, compared with field surveys for its update, including the location of canals and drainage ditches altered by uncontrolled urbanization. The map of the micro drainage network was entirely built from plants and descriptive memorials of the paving projects in each of the streets in the study area and from the drainage projects of the streets, provided by the Department of Public Works. This information was found completely dispersed and was obtained from the identification of each street. To integrate the 
drainage network, the software AutoCAD 2011 was employed. The characteristics of Morro das Pedras basin and Rio Tavares basin were collected by integrating the information contained on the maps of hydrography, roads, hypsometry and the micro drainage network by means of the Quantum GIS (QGIS 2.1) application and AutoCAD 2011. The crossing of the attributes table of each map information has been accomplished with Esri ArcGIS.

The study of the vulnerability of the aquifer was based on the Study of East Coast Aquifer (Estudo do Manancial Subterrâneo da Costa Leste) [9]. This document was commissioned by the local sanitation company - CASAN, which was interested in determining the correct dimensioning of the groundwater extraction wells, with the definition of optimal conditions for exploitation, to prevent salinization of the productive zones. They were also interested in studying the vulnerability of the aquifer and proposing protection measures. GOD and DRASTIC methodologies were used for this work and was described in detail by Pacheco and Finotti [10]. In summary, GOD methodology is based on the evaluation of three parameters: groundwater occurrence $(G)$, overall lithology $(O)$ and depth to groundwater (D). The product of the normalized parameters (eqn 1) gives a numerical value between 0 (less vulnerable) and 1 (most vulnerable). DRASTIC methodology includes seven parameters: depth to aquifer (D), recharge to groundwater (R), aquifer material (A), soil type (S), topography or slope (T), unsaturated zone (I), hydraulic conductivity (C). Each parameter value is transformed in a rate (between 0 and 10) by using specific tables: $\mathrm{Dr}, \mathrm{Rr}, \mathrm{Ar}, \mathrm{Sr}, \mathrm{Tr}, \mathrm{Ir}, \mathrm{Cr}$. And to each parameter is assigned a weight to incorporate their relative importance: Dw, Rw, Aw, Sw, Tw, $\mathrm{Iw}, \mathrm{Cw}$. Vulnerability is then calculated by eqn (2)

$$
\mathrm{GOD}=\mathrm{G} \cdot \mathrm{O} \cdot \mathrm{D}
$$

DRASTIC $=(\mathrm{Di} \times \mathrm{Dp})+(\mathrm{Ri} \times \mathrm{Rp})+(\mathrm{Ai} \times \mathrm{Ap})+(\mathrm{Si} \times \mathrm{Sp})+(\mathrm{Ti} \times \mathrm{Tp})+(\mathrm{Ii} \times \mathrm{Ip})+(\mathrm{Ci} \times \mathrm{Cp})$

In the third phase, a synthesis map was developed, with the intersection of the information plans regarding the drainage network, the vulnerability of the Campeche aquifer and the location of the water resources. This map has allowed the identification of management conflicts related to water resources, arising from the lack of integration among managers, as presented by Pacheco and Finotti [10].

The most critical areas identified by the authors were then subjected to a historical analysis by means of the use of satellite images of different periods to identify the pressure that the process of urbanization has imposed on the water resources. This is the fourth phase of methodology. Finally, an assessment was made of the potential application of the use of the geotechnologies here described for the integrated management of urban water resources and the management of sanitation structures of the city. All available images of the areas studied were surveyed. There are images for the years: 1938, 1957, 1977, 1994, 2007 and 2012. Images were cut across geographical coordinates and were articulated in mosaics that allow a temporal comparison. From the mosaics, impacts on water resources have been identified and the works of macro drainage were surveyed and deployed on the sites.

\subsection{Characterization of study area}

This research was conducted in the municipality of Florianópolis, Santa Catarina, located between the geographic coordinates $27^{\circ} 10^{\prime}$ and $27^{\circ} 50^{\prime}$ south latitude and between $48^{\circ} 25^{\prime}$ and $48^{\circ} 35^{\prime}$ west longitude. The Campeche district is located in the insular part of the municipality of Florianópolis, and it is a part of the southern area of the island. The area selected for the study was the area contributing to the Campeche aquifer, bounded according to the planning territorial units (UTPs) proposed 

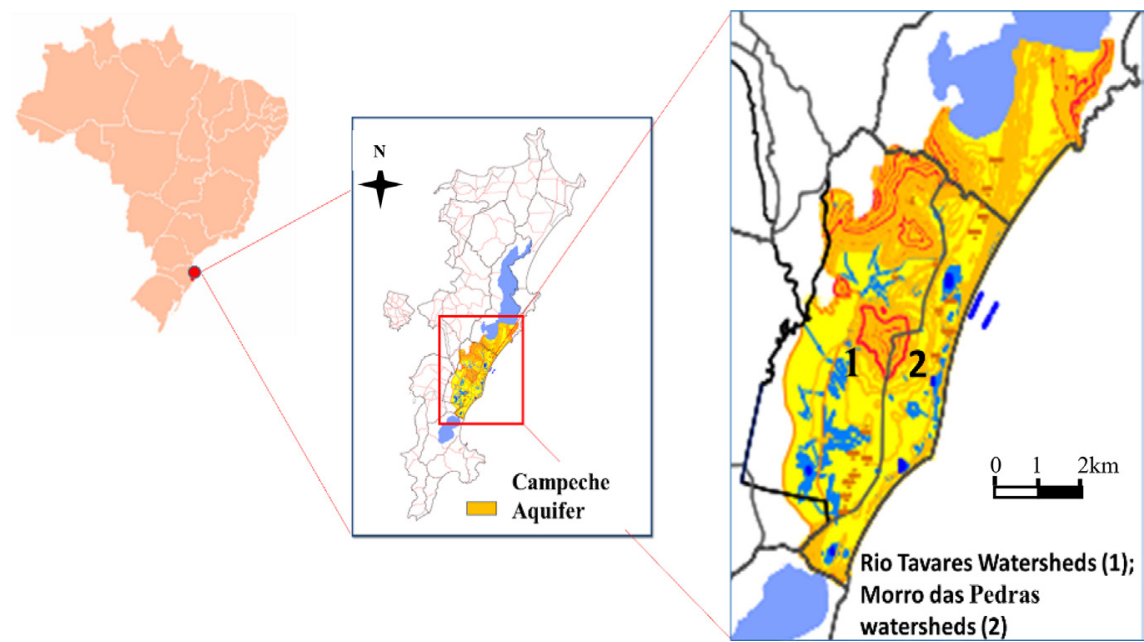

Figure 1: Delimitation of the study area [8].

by the PMISB of Florianópolis [8]. The area studied is on the UTPs of Rio Tavares, Morro das Pedras and Lagoa da Conceição (Fig. 1). The environmental aspects considered most relevant to the study were hydrography, hypsometry and characterization of the Campeche aquifer. It is an area with many conflicts in terms of land use and natural resources. There is a very high touristic interest in the site, as well as real-estate speculation. From the environmental point of view, the site presents various environments protected by law, such as mangrove, areas of sand dunes and restinga (sandbanks).

\section{RESULTS AND DISCUSSION}

\subsection{Diagnostic of the urban water of the Campeche district - maps reconstitution}

The diagnostic of the urban water of the Campeche district was based on the map of Land Use Planning of Florianópolis and in the construction of two other maps or information plans: hydrography and urban drainage. Hydrograph map, shown in Fig. 2, was constructed by crossing hypsometry and a map containing only rivers layout.

For the drainage map (Fig. 3), the main challenge encountered was the compilation of documents and tracing the network of basin drainage. Information about the drainage network was entirely dispersed in projects for each street some in paper and other in Autocad archives. Furthermore, a lack of supervision of fieldworks that do not document the changes in the original project during construction was identified and there was no update of executive projects. A record of the project 'as built' is not required, which results in a downgrade of the drainage projects database of the municipality [11].

It can be seen from the map of the drainage network (Fig. 3) that the only natural river channel that coincided with drainage channels was located near Lagoa Pequena, an area of high vulnerability because it is a discharge from the aquifer. The other stormwater effluents with high levels of pollutants are released in the mangrove of Rio Tavares or are infiltrated by the drain sinks, becoming contaminants injection systems in the Campeche aquifer. 


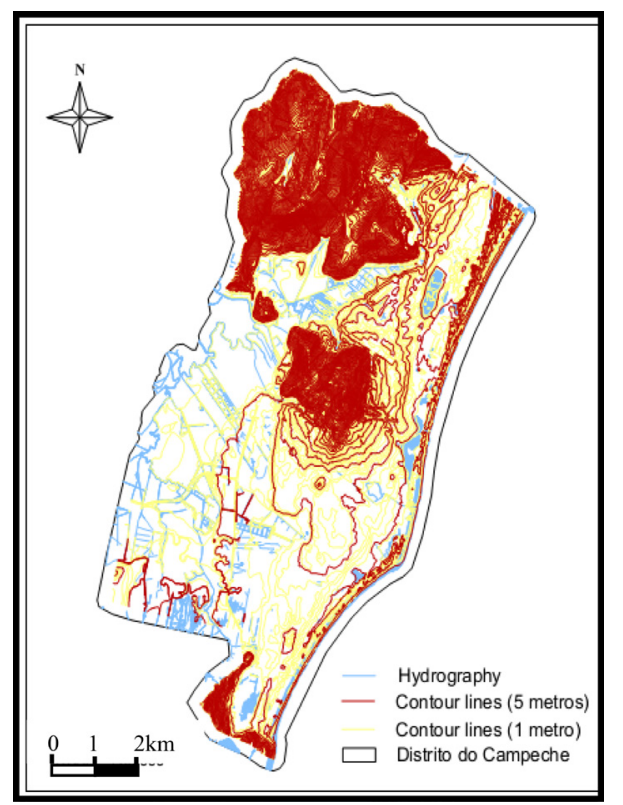

Figure 2: Hydrography and hypsometry maps.

The sanitation information survey in the region $[8,10]$ has allowed the identification of two additional pressures on the Campeche aquifer. Water supply is partially conducted with an underground catchment in the Campeche aquifer in three wells and a catchment of surface water in Rio Tavares. The remaining water comes from other watersheds. The collection system of wastewater from the Campeche district is being installed, but there is no sewage treatment station yet. Currently, treatment is performed by means of individual septic systems, anaerobic filters and drains or swales. However, much of the plain can be flooded (marshes, swamps, pounds and mangroves) and is at low altitudes, increasing the saturation of the water table and the widespread flooding after frequent rains, which chronically impose the reflux of domestic septic tanks in many houses in the area.

The problem of frequent flooding and environmental contamination by urban drainage are complex problems. The solution starts with a diagnosis of its origins and usually demands the implementation of a new approach to urban drainage management. The adoption of principles of low impact development is one alternative that have shown very good results worldwide since it attacks the problem of flooding and water resources contamination by urban drainage and present cost benefits in comparison to urban drainage traditional approach.[12,13].

\subsection{Analysis of the impacts of stormwater management on water resources - synthesis map}

3.2.1 Study on the vulnerability of the Campeche aquifer

The study on the vulnerability of the Campeche aquifer was based on the Study of East Coast Underground Water Source (Estudo do Manancial Subterrâneo da Costa Leste); this document was commissioned by CASAN and based on two methodologies: GOD and DRASTIC. Its application has presented as a final product the map of natural vulnerability of the Campeche aquifer. By the 


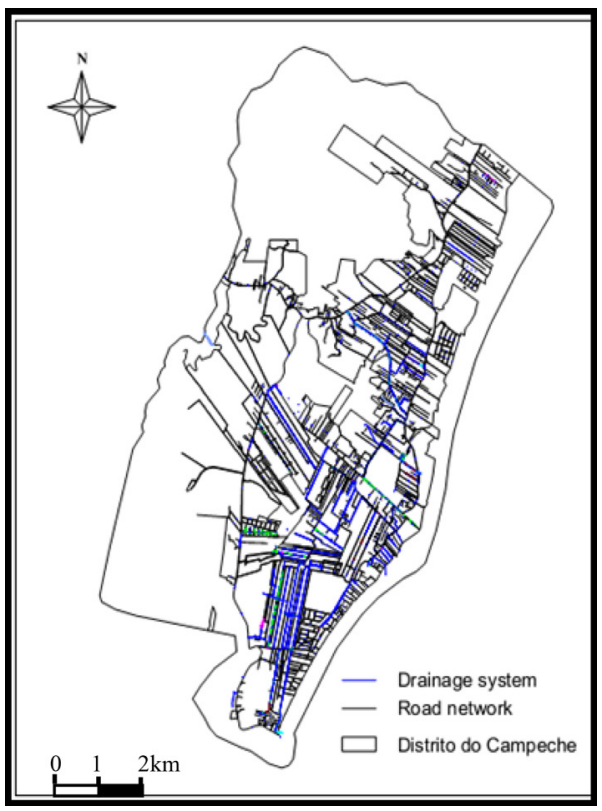

Figure 3: Drainage system and roads.

GOD methodology, the coastal aquifer system of Campeche presents a vulnerability index equal to 0.8 ( 0 is least vulnerable and 1 is most vulnerable). The range $0.8-1$ comprises the one of extreme vulnerability values. The details of such methodologies and the vulnerability map were presented in Pacheco and Finotti [10]. The vulnerability map was integrated with other maps to build up the synthesis map shown in Fig. 4.

\subsubsection{Intersection of the information plans}

The intersection of the information plans was developed by superimposing the map of drainage and hydrology network on the vulnerability map of the Campeche aquifer, resulting in the synthesis map in Fig. 4. The analysis of the synthesis map identified the regions of greatest vulnerability of the aquifer, highlighted in that figure. The main characteristics analysed were the structural measures used for the launch of the drainage network, the relationship and the influence of these on water bodies (rivers, ponds and marshy areas) as well as their impacts on the groundwater sources. Furthermore, the use of the canals and their influence on the hydrography of the region and the increased flooding due to channelling river stretches were sometimes randomly performed by individuals. The critical regions identified in the synthesis map are: Region 1 - Lagoa Pequena, Region 2 - Riozinho do Campeche, Region 3 - Rio Tavares, Region 4 - Lagoa da Chica, Region 5 - Norbecker Gated Community and Region 6 - Morro das Pedras. In Table 1, the main impacts of urban drainage on water resources identified from the synthesis map and fieldwork are presented.

\subsubsection{Assessment of the historical series of images of critical areas}

Region 1 - Lagoa Pequena. Lagoa Pequena has a total area of approximately $186,372 \mathrm{~m}^{2}$. It is the most important upwelling of water table in the Campeche Plain, and, from a hydrogeological point 


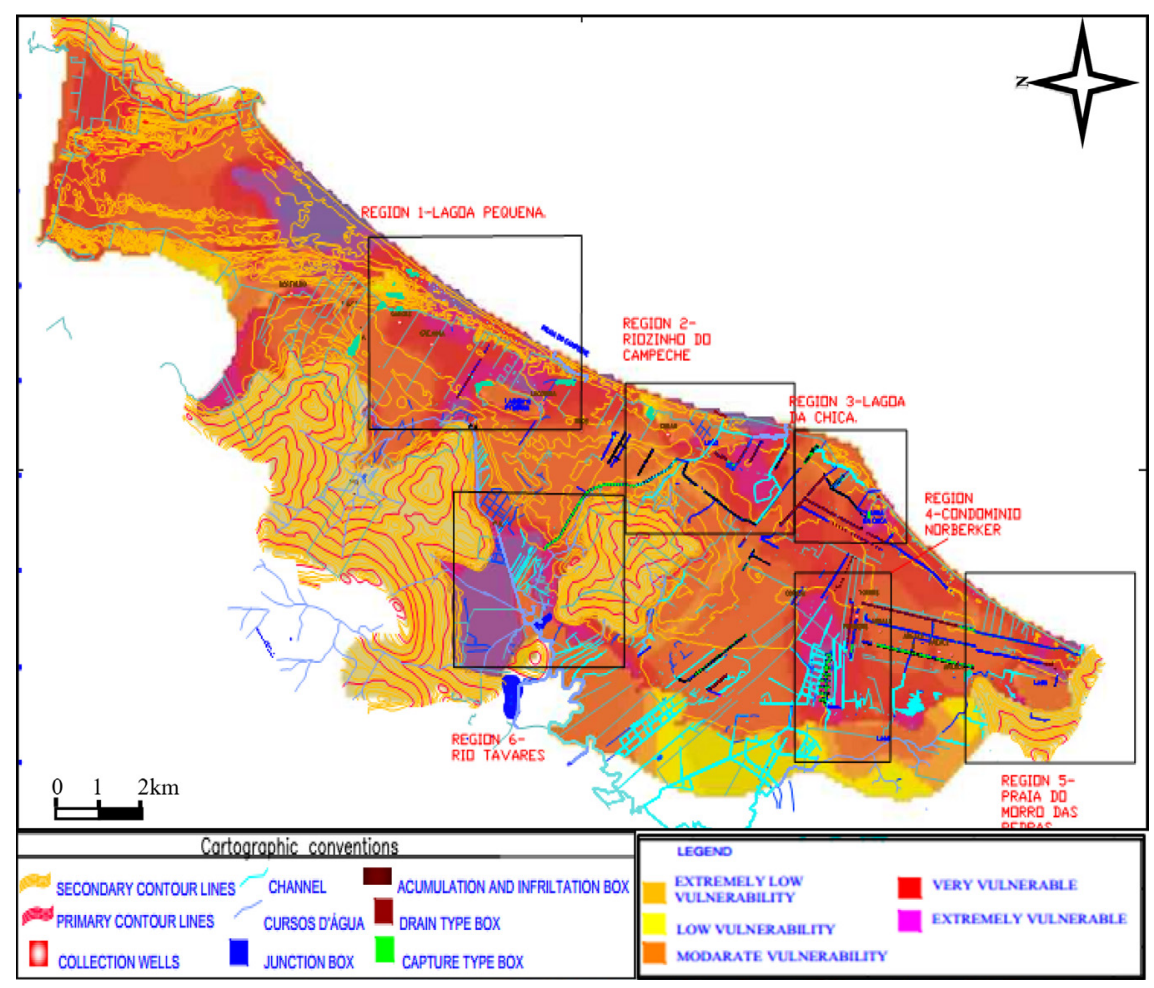

Figure 4: Synthesis map of hydrography, vulnerability and urban drainage system [10].

of view, it forms the Santa Catarina Island, major sub-basin [14]. When the lagoon overflows and overlaps into the secondary bed, the water runs off through a channel southeast of the lagoon and between the dunes, forming swamps that slowly seep into the Riozinho river and reach the Campeche beach [10].

The history of images of the area is presented in the mosaic of Fig. 5. It is noticed that Lagoa Pequena has a seasonal variation in its water level due to climatic factors, including precipitation and evapotranspiration, which show variations throughout the years and decades, according to local climatology. This variation can be seen in image b of the mosaic (Fig. 5), which shows a high-level moment of the system, while other images show low levels. Such episodes are especially critical because, as the Lagoa Pequena is an outcrop of the Campeche aquifer, infiltration of waters is impossible when the level is high, and the drainage system may face runoff problems.

The level of the Lagoa Pequena has also suffered anthropogenic influence causing an event of drought in the early 1990s, as shown in image c (Fig. 5). After that, there was an invasion and urbanization of the conservation area of the largest bed of the Lagoa. In the images, a progressive increasing of urbanization is observed, with an almost total disappearance of the dunes observed in the vicinity of image a and the urban occupation of image f. According to Brazilian legislation [14], in the vicinity of Lagoa Pequena, there should be a 30-m wide preservation range from the highest water level.

Region 2 - Riozinho do Campeche. Riozinho do Campeche has its source in Morro do Lampião and receives stormwater and sewage effluents from important streets. This river has problems of 


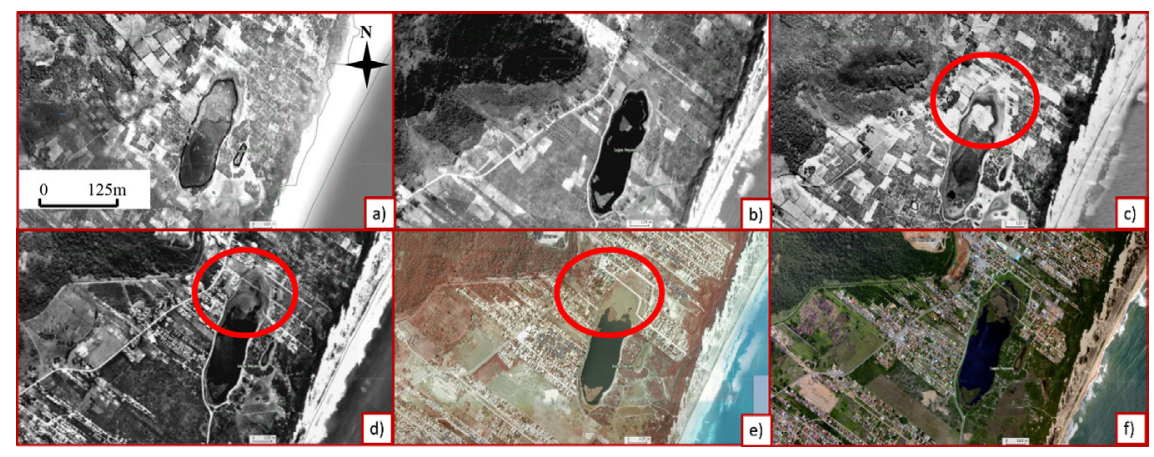

Figure 5: Lagoa Pequena images mosaic: 1938 (a), 1957 (b), 1977 (c), 1994 (d), 2007 (e) and 2012 (f).

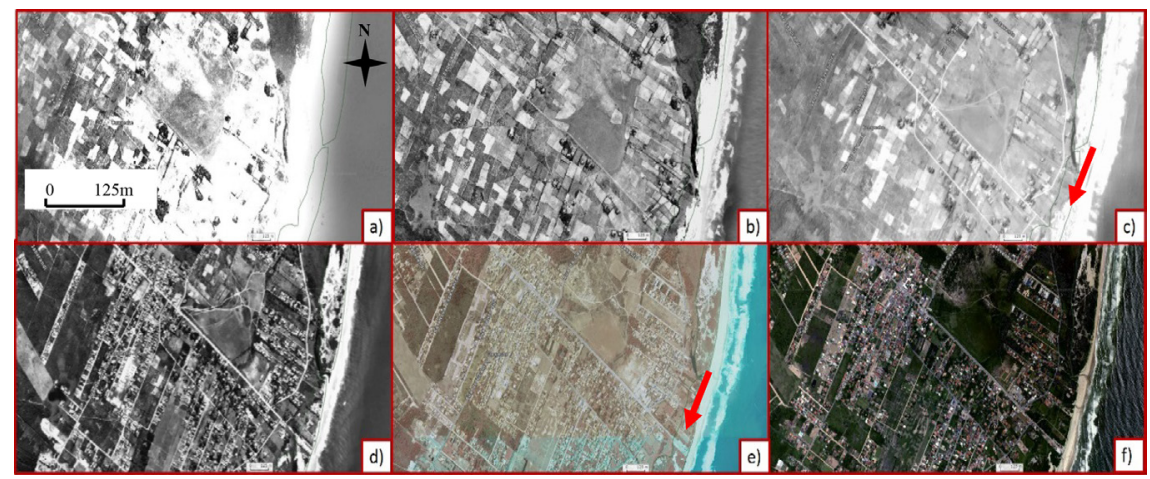

Figure 6: Riozinho do Campeche images mosaic: 1938 (a), 1957 (b), 1977 (c), 1994 (d), 2007 ( e) and 2012 (f).

illegal connections of residential sewer lines built improperly into restinga and mobile-dune areas. It is located in an area of extreme vulnerability of the aquifer. In this region, we observed wetlands, drainage ditches and an abstraction well, as well as the straightening of some of the rivers that contribute water to the aquifer [10].

The mosaic images shown in Fig. 6 present a very fast urbanization between years 1977 and 1994. In images $\mathrm{c}$ and e, we can see an illegal embankment in part of Riozinho stream followed by an illegal occupation of the area by construction of houses. This occupation caused several episodes of local documented flooding after 1994.

Region 3 - Rio Tavares. Rio Tavares originates in the eastern part of the Massif Central, heading south until joining the Rio Tavares mangrove. It flows from areas of high population density to areas of great biodiversity and ecological significance, such as the Rio Tavares mangrove, which is a biome protected by the Brazilian Federal Law [14]. From the surveyed drainage network and according to the available data, the region has significant sources of pollution from urban drainage and wastewater [10].

The area mosaic images (Fig. 7) allows the verification of how the enlargement of the drainage channel, identified by the red arrow, has modified the wetlands on site until image b in year 1957 


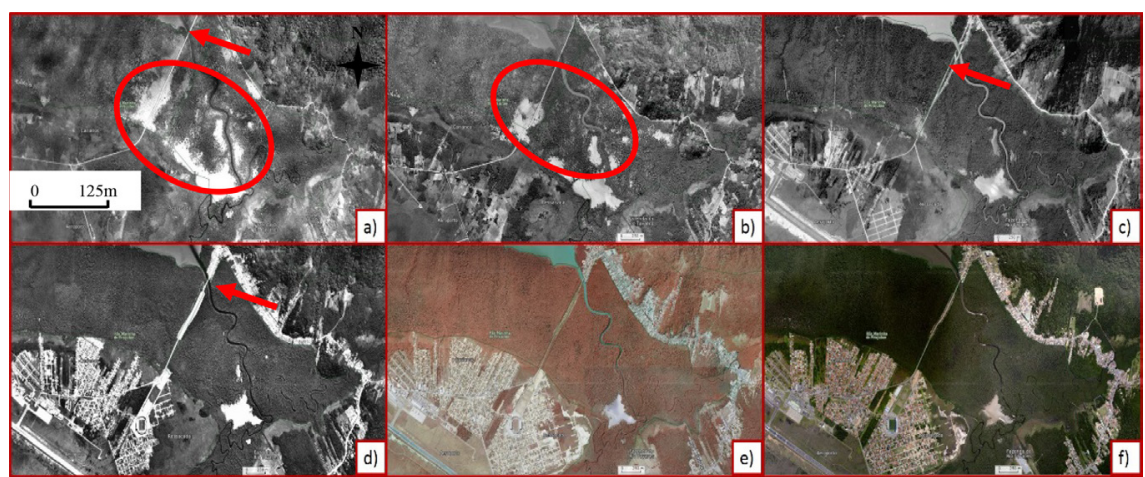

Figure 7: Rio Tavares images mosaic: 1938 (a), 1957 (b), 1977 (c), 1994 (d), 2007 (e) and 2012 (f).

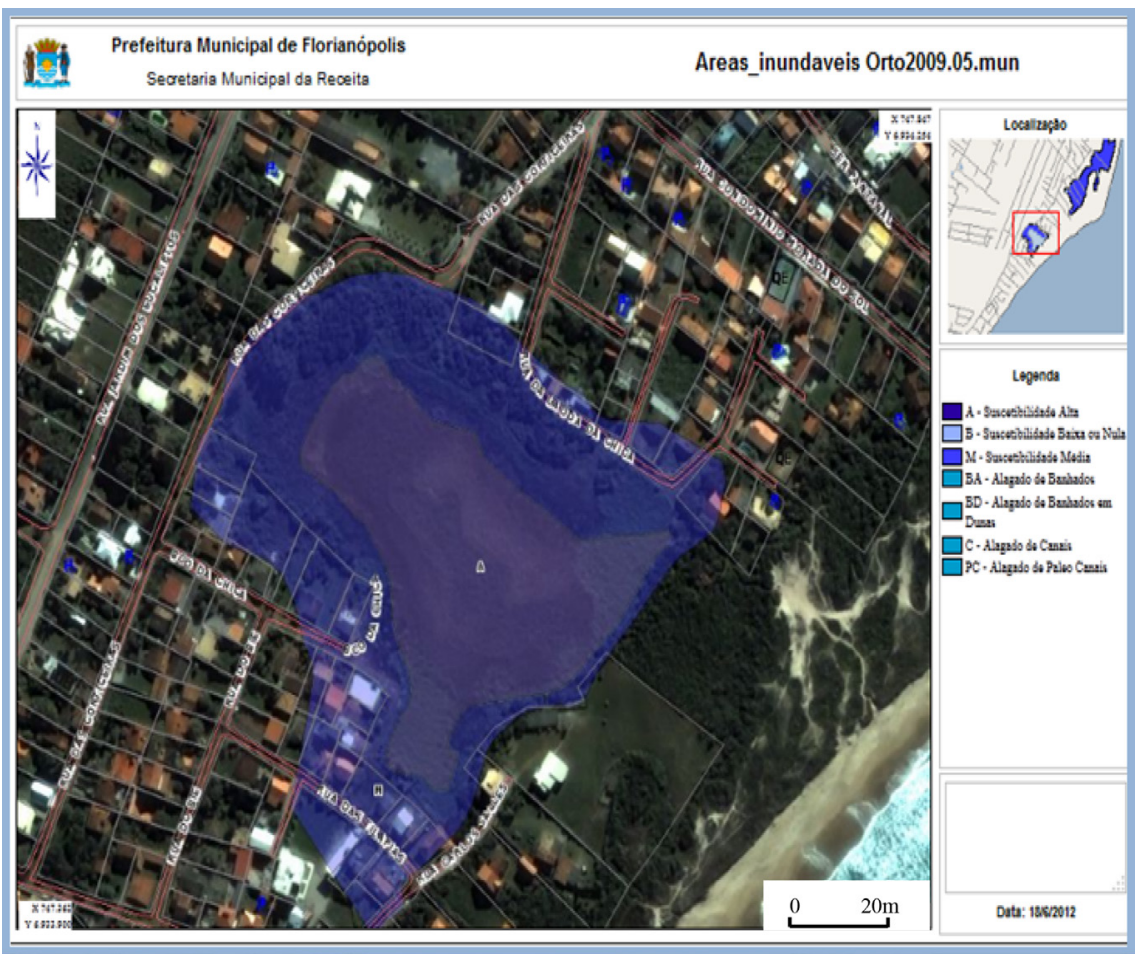

Figure 8: Flooding region of the Lagoa da Chica [16].

circled in red. The work has virtually dried up the area and allowed the occupation of the portion shown in the bottom left corner of the images. The density of occupation between 1977 and 1994 is remarkable and worsens in the following images. The dried and later occupied area corresponds to many gated communities and one of them is Norbecker, previously identified in this study and detailed below. 
Region 4 - Lagoa da Chica. The region of Lagoa da Chica is located in an area of extreme vulnerability of the Campeche aquifer. The lagoon (Lagoa da Chica) is a highly degraded environment due to the gradual reduction of its water level as a result of both the sedimentation caused by the erosion of nearby embankments and interventions in and diversion of water bodies that used to flow in the same direction [15]. The local population uses septic tanks, and the pollutant load is complemented by the washing of the streets, which injects these pollutants into the aquifer through leaching pits connected to a thin unsaturated zone.

Currently, Lagoa da Chica is nearly all silted up due to the following factors: construction, advancing urbanization, rainwater drainage network connection and lowering of the aquifer. The region has no oversight of guidelines for soil use and occupation. The occupation of the floodplain of the pond can be seen in the image of Fig. 8.

Region 5 - Norbecker gated community. The Norbecker Gated Community has the largest concentration of drainage ditches that carry water to the Rio Tavares mangrove, featuring four wells used to abstract water for public supply and some wetland and flood-hazard areas. The drainage network uses only storage tanks that discharge their effluents into drainage ditches, without any pretreatment or, at most, with the use of a geotextile fabric. In this region, infiltration basins are periodically constructed by gated communities by delimiting an area to control the flow of the stormwater effluents collected. It is noteworthy that these structures do not always work properly and occasionally cause downstream flooding.

The images of the mosaic of the region of the Norbecker Gated Community (Fig. 9) clearly show how the implementation of the drainage canals alters the movement of water, dries historically flooded areas and allows urban occupation. The red arrows indicate the implantation of drainage canals that come with each new image. Following the drainage canals comes the intensification of the urban settlement in areas initially protected by law due to the presence of water.

Region 6-Morro das Pedras. The region of Morro das Pedras has three collection wells operated by CASAN, with some wetland areas and vestiges of a lake that dried up over the years (Fig. 10). This is not an area of extreme vulnerability of the aquifer, but the presence of wells can induce the seepage of pollutants into the aquifer.

The drainage network consists of channels, galleries, simple collection tanks and leaching pits. It has a flood-hazard zone upstream of the river stretch that was straightened, which was defined as a

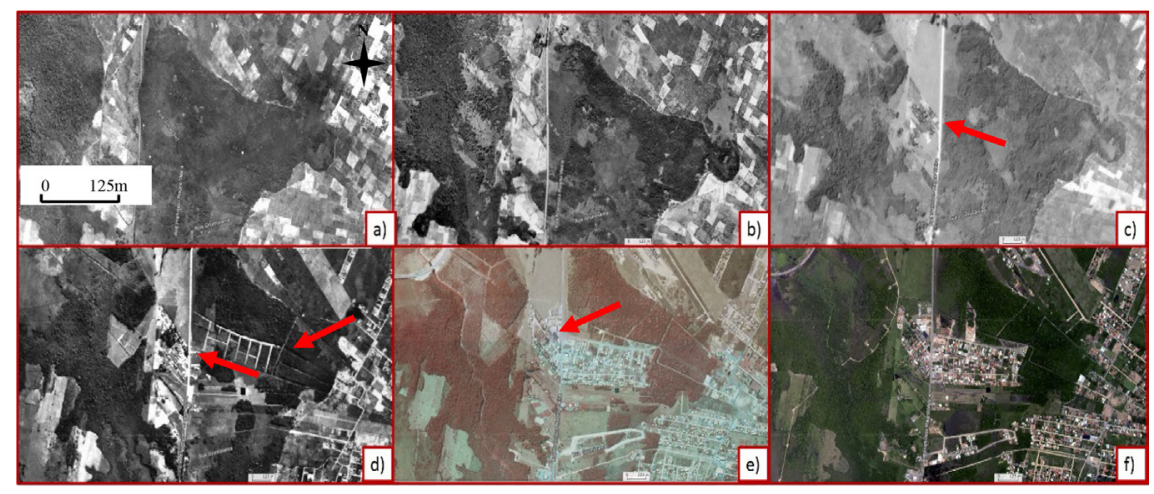

Figure 9: Norbecker Gated Community images mosaic: 1938 (a), 1957 (b), 1977 (c), 1994 (d), 2007 (e) and 2012 (f). 


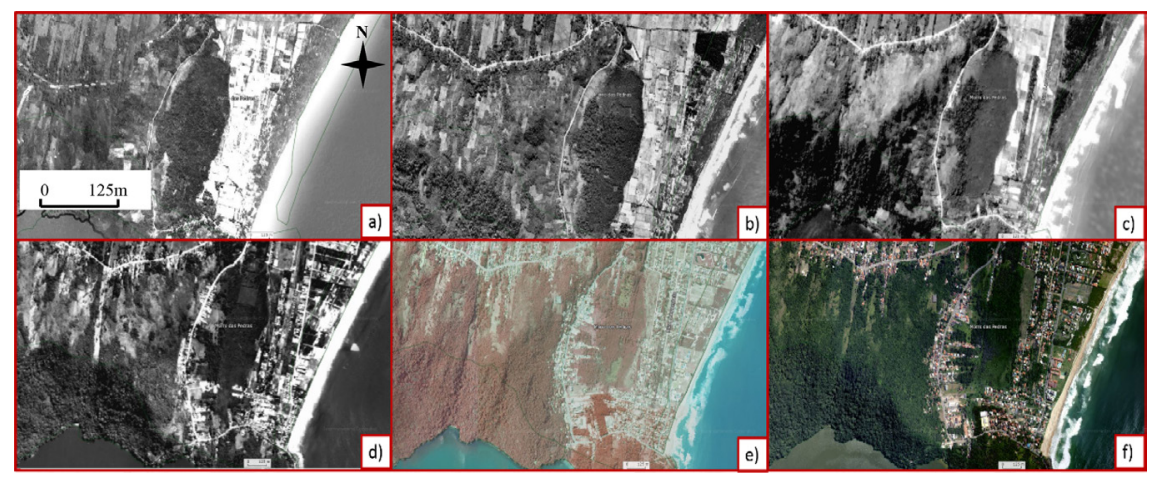

Figure 10: Morro da Pedras images mosaic: 1938 (a), 1957 (b), 1977 (c), 1994 (d), 2007 (e) and 2012 (f).

critical area by the PMISB and contributed water to the lake that has dried up. All of the drained volume that is not discharged into the beach dunes of Morro das Pedras is disposed into this region.

The problems encountered with the use of the synthesis map and fieldwork were presented by Pacheco and Finotti [10] in a matrix of impacts. The new impacts identified by applying the geotechnology of historical satellite images analysis are presented in Table 1 as a refinement of the previous matrix. New impacts identified are shown in grey in Table 1.

By cross-checking data layers, it was possible to develop a matrix of the impacts, as shown in Table 1. This technique allows for an interdisciplinary approach to the problem and points to more comprehensive control measures. Using satellite images, mosaics allowed a detailed observation of the processes taking place during urbanization. Also allowed the verification that after a interference in the water bodies, such as drying of natural flooded areas and lagoons or straightening of river meanders, the urbanization process was intensified. Some impacts could only be detected in the historical analyses of the area due to the use of mosaic images as shown in Table 1. It is a very good complement to the water resources and drainage management.

The approach to urban drainage management adopted in the study area favours a traditional perspective in which watershed management or more sustainable practices [17] are not incorporated. Practices that promote a more sustainable management of drainage systems and water resources have been increasingly recommended [18-20], despite the mismatches between what is proposed by these studies and the actual actions taken by administrative bodies [17]. In the specific case investigated, the lack of integration between the sectors is a major gap that allows these problems to keep happening and to have a larger and larger impact on the local environment. From the impacts identified in the work, Pacheco and Finotti [10] have made a list of mitigation measures applicable to the area.

Using the historical series of satellite images of areas allows the recovery of the water network over time. Without the use of the images, reconstitution is possible only by means of old maps or reports from people who have inhabited the site or from any other historical record, which is quite laborious and not always possible to accomplish. The images and geotechnologies also allow the identification of the impacts that each new work of macro drainage, such as the construction of canals and watercourses corrections, impose on water resources and, consequently, land use. The identification and documentation of the environmental impacts by means of the images allow the 
Table 1: Matrix of environmental impacts in the most vulnerable regions of Campeche aquifer (after Pacheco and Finotti [10]).

\begin{tabular}{|c|c|c|c|c|c|c|}
\hline Regions in the synthesis map & & & & & & \\
\hline Environmental impacts & 1 & 2 & 3 & 4 & 5 & 6 \\
\hline Presence of wells for abstracting water from the aquifer for public supply & $\mathrm{x}$ & $\mathrm{x}$ & & & $\mathrm{x}$ & $\mathrm{x}$ \\
\hline Outcrop of the aquifer in the form of a lagoon & $\mathrm{x}$ & & & $\mathrm{x}$ & & \\
\hline Burial of water bodies (lagoons or rivers or channels) & $\mathrm{X}$ & $\mathrm{x}$ & & $\mathrm{x}$ & & \\
\hline $\begin{array}{l}\text { Illegal occupation of the area containing water resources or the portion } \\
\text { within the preservation area }\end{array}$ & $\mathrm{X}$ & $\mathrm{x}$ & $\mathrm{x}$ & $\mathrm{x}$ & $\mathrm{x}$ & $\mathrm{x}$ \\
\hline Deforestation of restinga vegetation & $\mathrm{X}$ & $\mathrm{x}$ & & & $\mathrm{x}$ & \\
\hline Clogging of lagoon beds & $\mathrm{x}$ & & & $\mathrm{x}$ & & \\
\hline Siltation of the watercourse & & & $\mathrm{x}$ & & & \\
\hline Straightening of meanders in the watercourse & & $\mathrm{x}$ & & & & $\mathrm{x}$ \\
\hline Channelization of watercourses & & $\mathrm{x}$ & $\mathrm{x}$ & & $\mathrm{x}$ & \\
\hline Opening of a channel connecting the lagoon or flooded area with the sea & $\mathrm{x}$ & & $\mathrm{x}$ & & $\mathrm{x}$ & \\
\hline $\begin{array}{l}\text { Blockages or burial of the channel connecting the lagoon with other water } \\
\text { bodies }\end{array}$ & & & & $\mathrm{x}$ & & \\
\hline $\begin{array}{l}\text { Interventions in or diversion of the riverheads that contribute water, thus } \\
\text { changing the water balance and the lagoon area }\end{array}$ & & & & $\mathrm{x}$ & & \\
\hline Use of stormwater infiltration structures in the Campeche aquifer & $\mathrm{x}$ & $\mathrm{x}$ & & $\mathrm{x}$ & $\mathrm{x}$ & $\mathrm{x}$ \\
\hline Discharge of stormwater effluents directly into the river & & & $\mathrm{x}$ & & & \\
\hline Occurrence of floods & $\mathrm{x}$ & $\mathrm{x}$ & $\mathrm{x}$ & $\mathrm{x}$ & $\mathrm{x}$ & $\mathrm{x}$ \\
\hline Presence of septic tanks & & $\mathrm{x}$ & & $\mathrm{x}$ & $\mathrm{x}$ & \\
\hline Illegal connections of sewer lines to the lagoon or river & $\mathrm{x}$ & $\mathrm{x}$ & $\mathrm{x}$ & & & \\
\hline Tidal variations that prevent stormwater runoff & $\mathrm{x}$ & & $\mathrm{X}$ & & & \\
\hline
\end{tabular}

environmental impact assessment and the study of the human occupation procedures associated with water resources, which is an important scientific contribution that could provide major breakthroughs, as the geotechnologies allow to gather even more information from satellite images.

\section{CONCLUSIONS AND RECOMMENDATIONS}

The district of Campeche is a region characterized by high real-estate speculation and uncontrolled population growth, resulting in irreversible impacts on the sensitive environments of its plain. Even though Campeche is rich in biodiversity, water resources and areas for urban development attitudes taken individually, without consulting qualified technical personnel and with no environmental planning, will lead to the depletion of its water resources and the degradation of its environment. The main water sources and bodies of water of the Campeche district have been suffering degradation, which reflects the lack of urban planning and causes siltation of rivers and lakes [10].

In urban drainage, there is frequent use of structural measures without a plan linked to a Stormwater Management Plan. Drainage projects are performed as a result of street paving. The 
implementation of a sewage system must be followed by guidance and supervision so that connections are made correctly in the sewage system rather than in the rainwater system, and deactivation of septic tanks is also crucial. It is highly advisable that an inventory of the drainage network and all hydrography and infrastructure in the region should be made and standardized, to accomplish and fulfil the stormwater management plan. One of the difficulties faced while conducting this study was to unify the sets of data provided by the city management agencies of Florianópolis, which diverged from each other. Difficulties regarding data acquisition and processing were overcame by the intervention of specialized technical personnel that could unify information in a GIS database. The unification allowed cross checking of plan information that could aid diagnosis of potential problems. The database could also be used for urban drainage planning purposes.

Besides the integration of information plans and the use of GIS as a complementary tool of drainage planning, we presented in this work a methodology to aid the identification of water resources and urban drainage impacts. The use of image analysis showed as a very important tool in the diagnosis, planning and management of urban drainage. But we could diagnosis also that the lack of technical personnel to manipulate the images and to plan drainage is one of the most impeditive points to the widespread use of the methodology presented in this article. Another key point is the lack of articulation within the city halls.

\section{ACKNOWLEDGEMENTS}

The authors thank CNPq (National Council of Scientific and Technological Development) for supporting Professor Alexandra Finotti' research project, Santa Catarina State Water and Sanitation Utility - CASAN, Municipality of Florianópolis and CAPES (Coordenação de Aperfeiçoamento de Pessoal de Nível Superior) for funding authors participation in Water Pollution Conference.

\section{REFERENCES}

[1] Vargas, M.C. O gerenciamento integrado dos recursos hídricos como problema socioambiental. Ambiente \& Sociedade, 5, pp. 11-14, 1999. doi: http://dx.doi.org/10.1590/s1414-753x1999000200009

[2] Política Nacional de Recursos Hídricos, Brazil, Lei 9344/1997, available at: www.mma.gov. br, 1997.

[3] Política Nacional de Saneamento Básico, Brazil, Lei 10.350/2007, available at: www.mma. gov.br, 2007.

[4] Todeschini, S., Papiri, S. \& Sconfietti, R., Impact assessment of urban wet weather sewer discharges on the Vernavola river (Northern Italy). Civil Engineering and Environmental Systems, 28(3), pp. 209-229, 2011. doi: http://dx.doi.org/10.1080/10286608.2011.584341

[5] Todeschini, S., Ciaponi, C. \& Papiri, S., Stormwater quality control for sustainable urban drainage systems. Int. Journal of Sustainable Development and Planning, 9(2), pp. 196-210, 2014. doi: http://dx.doi.org/10.2495/sdp-v9-n2-196-210

[6] Tucci, C.E.M., Gestão da água no Brasil, UNESCO: Brasília, 2001.

[7] Maidment, D., Handbook of Hydrology, McGraw Hill: New York, 1993.

[8] PMISB, Plano Municipal Integrado de Saneamento Básico de Florianópolis, Prefeitura Municipal de Florianópolis, 2011.

[9] CASAN, Estudo do Manancial Subterrâneo da Costa Leste Campeche, Município de Florianópolis, Executado por Engenharia e Pesquisas Tecnológicas: Florianópolis, 2002.

[10] Pacheco, E.F. \& Finotti, A.R., Interfaces between traditional urban drainage systems and water resources: case study: Rio Tavares and Morro das Pedras watersheds Florianópolis/ Brazil, WIT Transactions on Ecology and the Environment, 182, pp. 187-199, 2014, ISSN 1743-3541. doi: http://dx.doi.org/10.2495/wp140171 
[11] Pacheco, E.F. \& Finotti, A.R., Qualitative and quantitative evaluation of stormwater infiltration structures in an urban basin. Case study: District of Campeche, Florianópolis-SC. Proc. of the 6th International Conference on Flood Management, ABRH: São Paulo, 2014.

[12] Chocat, B., Krebs, P., Marsalek, J., Rauch, W. \& Schilling, W., Urban drainage redefined: from stormwater removal to integrated management. Water Science \& Tech., 43(5), pp. 61-68, 2001.

[13] USEPA, Case studies analyzing the economic benefits of low impact development and green infrastructure programs, EPA Report 841-R-13-004, USEPA, Washington, 2013.

[14] Conama (Conselho Nacional de Meio Ambiente) Resolução 005/1985, Ministério do Meio Ambiente do Brasil, available at: www.mma.gov.br, 1985.

[15] Prefeitura Municipal de Florianópolis. Secretaria Municipal de Planejamento, Geoprocessamento Corporativo, available at: geo.pmf.sc.gov.br/geo_fpolis/.

[16] Engevix, Florianópolis, Projeto de macrodrenagem do distrito do Campeche, Relatório final. Outubro, 2002.

[17] Cettner, A., Ashley, R., Hedstrom, A. \& Viklander, M., Sustainable development and urban stormwater practice. Urban Water Journal, 11(3), pp. 185-197, 2014.

[18] Doubleday, G., Sebastian, A., Luttenschlager, T. \& Bedient, P.B., Modeling hydrologic benefits of low impact development: a distributed hydrologic model of the Woodlands, Texas. Journal of the American Water Resources Association, 49(6), pp. 1444-1455, 2013. doi: http://dx.doi. org/10.1111/jawr.12095

[19] Qin, H., Li, Z. \& Fu, G., The effects of low impact development on urban flooding under different rainfall characteristics. Journal of Environmental Management, 129, pp. 577-585, 2013. doi: http://dx.doi.org/10.1016/j.jenvman.2013.08.026

[20] Ellis, J.B., Revitt, D.M. \& Lundy, L., An impact assessment methodology for urban surface runoff quality following best practice treatment. Science of the Total Environment, 416, pp. 172-179, 2012. doi: http://dx.doi.org/10.1016/j.scitotenv.2011.12.003 